\title{
Job Satisfaction of Bank Employees in Bangladesh
}

\author{
Md. ShamimHossain \\ Lecturer, Department of Business Administration, Dhaka International University \\ 66, Green Road, Dhaka-1205, Bangladesh \\ E-mail of the corresponding author:md.shamimdu@gmail.com
}

\begin{abstract}
This study attempts to evaluate job satisfaction of bank employees in Bangladesh. It focuses on the relative importance of job satisfaction factors and their impacts on the overall job satisfaction of employees. In this study the targeted population is employees of Bank. The Banks include private and public Bank. The data was collected and administered by means of a structured questionnaire. The study showed that organizational factors such as work conditions, pay, fairness, and promotion significantly influenced employee job satisfaction in Bank. However, individual factors such as age and gender did not significantly influence employee job satisfaction in Banks. The overall job satisfaction of the bank officers is at the positive level appeal to their customers. In such situation, job satisfaction of bank officers becomes an important issue that has to be taken care of in order to achieve ultimate goals of the banking sector in Bangladesh.
\end{abstract}

Keywords:Job Satisfaction, Work Condition, Pay, Fairness, Promotion, Age, Gender.

\section{Introduction}

In recent years, economic development in the world makes the rapid development of the Bangladesh bank industry. However, this rapid expansion has also generated a lot of internal management problems in Banks. One special issue is the low level of employee job satisfaction that brought difficulties in increasing service quality. Some of the problem exist in current Bank are: long working hours, work pressure, low level of treatment, bad working environment, less promotion opportunities, work unfairness etc. Employee's job satisfaction affects the quality of Bank service, has affect the degree of customer satisfaction. Thereby great efforts to improve employee's job satisfaction, creates the satisfied customer with satisfied employees. Although there are many studies on employee job satisfaction, they are related to all aspects of employee job satisfaction. The employee satisfaction theory and employee satisfaction measurement tools and measurement indicators, as well as the impact of employee satisfaction factors, but in Bangladesh there are very limited studies on employee job satisfaction in Banks, specifically with respect to factors affecting job satisfaction. In this paper, through combining theoretical and empirical research, trying to find out factors affecting employees job satisfaction, Thereby laying the theoretical foundation for the practice, provide for future research on investigate factors affecting job satisfaction in Bank. By studying the factors affecting job satisfaction in Banks, we can effectively help the enterprise to understand the factors affecting employee job satisfaction; by understanding employee demands and requirements, one can also help the enterprise effectively manage employees and increase the management efficiency, increase the employee's loyalty and achieve a higher customer satisfaction.

Objectives

1. To determine the influence of work conditions on employee job satisfaction in Banks.

2. To identify the influence of pay on employee job satisfaction in Banks.

3. To examine the influence of fairness on employee job satisfaction in Banks.

4. To investigate the influence of promotion on employee job satisfaction in Banks.

5. To determine the influence of age on employee job satisfaction in Banks.

6. To determine the influence of gender on employee job satisfaction in Banks.

\section{Scope of the study}

This study covers the factors affecting job satisfaction in Banks. The organizational factors include work conditions, pay, fairness and promotion; individual factors include age and gender, they are the independent variables; job satisfaction is the dependent variable.

\section{Literature Review}

One of the biggest preludes to the study of job satisfaction was the Hawthorne studies. These studies (19241933), primarily credited to Elton Mayo of the Harvard Business School, sought to find the effects of various conditions (most notably illumination) on workers' productivity. These studies ultimately showed that novel changes in work conditions temporarily increase productivity (called the Hawthorne Effect). It was later found that this increase resulted, not from the new conditions, but from the knowledge of being observed. This finding provided strong evidence that people work for purposes other than pay, which paved the way for researchers to investigate other factors in job satisfaction.Scientific management also had a significant impact on the study of job satisfaction. Principles of Scientific Management argued that there was a single best way to perform any given work task. The initial use of scientific management by industries greatly increased productivity because 
workers were forced to work at a faster pace. However, workers became exhausted and dissatisfied, thus leaving researchers with new questions to answer regarding job satisfaction. Some argue that Maslow's hierarchy of needs theory, a motivation theory, laid the foundation for job satisfaction theory. This theory explains that people seek to satisfy five specific needs in life - physiological needs, safety needs, social needs, self-esteem needs, and self-actualization. This model served as a good basis from which early researchers could develop job satisfaction theories. There are many methods for measuring job satisfaction. By far, the most common method for collecting data regarding job satisfaction is the Likert scale (named after RensisLikert). Other less common methods of for gauging job satisfaction include: Yes/No questions, True/False questions, point systems, checklists, and forced choice answers. This data are sometimes collected using an Enterprise Feedback Management (EFM) system. The Job Descriptive Index (JDI), created by Smith, Kendall, \&Hulin, is a specific questionnaire of job satisfaction that has been widely used. It measures one's satisfaction in five facets: pay, promotions and promotion opportunities, coworkers, supervision, and the work itself. The scale is simple, participants answer either yes, no, or can't decide (indicated by '?') in response to whether given statements accurately describe one's job. The Job in General Index is an overall measurement of job satisfaction. It is an improvement to the Job Descriptive Index because the JDI focuses too much on individual facets and not enough on work satisfaction in general. Other job satisfaction questionnaires include: the Minnesota Satisfaction Questionnaire (MSQ), the Job Satisfaction Survey (JSS), and the Faces Scale. The MSQ measures job satisfaction in 20 facets and has a long form with 100 questions. The JSS is a 36 item questionnaire that measures nine facets of job satisfaction. Finally, the Faces Scale of job satisfaction, one of the first scales used widely, measured overall job satisfaction with just one item which participants respond to by choosing a face.

\section{Methodology of the Study}

The information was collected by using the quantitative questionnaires. Firstly, the research process has been identified and the research problems have been formulated. Then, there were also a discussion about the instruments to be used and the decisions that should be made for achieving the purpose of the research. After that, the research design was created to answer the research objectives or hypotheses. As a quantitative study, conclusions are based on the questionnaires distributed to respondents. This quantitative study used statistical data as a medium to obtain the needed information. This study aims to determine the relations between the independent variables and the dependent variable. The findings and the conclusion of the study will solely depend on the full utilization of the statistical data collected.In this study the population targeted employees of Banks (The banks include Private and Public Banks). A simple random sampling technique was used in this study to select 50 employees from different Banks. While a wide range of instruments are used for measuring job satisfaction, section A will consist of questions related to the biographical information of the employees. Section $\mathrm{B}$ is related to overall job satisfaction, section $\mathrm{C}$ is related to factors affecting job satisfaction. Section $\mathrm{B}$ required respondents to rate items based on a 5-point Response format that is related to general factors affecting employee job satisfaction in Banks.

For example: 1 = Very unhappy, $2=$ somewhat happy, $3=$ Neither happy or unhappy, $4=$ Somewhat happy, $5=$ Very happy

Section $\mathrm{C}$ is related to the key factors that affects the employee job satisfaction.

A rating scale from 1 (strongly disagree) to 5 (strongly agree) was used.

$1=$ strongly disagree, 2 = disagree, $3=$ neutral, $4=$ agree, $5=$ strongly agree

All the 45 items were stated in the English language. The full questionnaire for the study is shown in Appendix A.

Table 1: shows the 45 items distributed into six (6) sub-dimensions namely: Details, Job Satisfaction, Work Conditions, Pay, Fairness, and Promotion.

\begin{tabular}{|l|l|}
\hline Sub-Dimensions & Item Number \\
\hline Details & 01D1, 02D2, 03D3, 04D4, 05D5, 06D6, 07D7,08D8, 09D9 \\
\hline Job Satisfaction & 10JS1, 11JS2, 12JS3, 13JS4, 14JS5, 15JS6 \\
\hline Work Condition & $\begin{array}{l}\text { 16WC1, 17WC2, 18WC3, 19WC4, 20WC5,21WC6, 22WC7 23WC8, 24WC9, } \\
\text { 25WC10 }\end{array}$ \\
\hline Pay & 26P1, 27P2 \\
\hline Fairness & 28F1, 29F2, 30F3, 31F4, 32F5, 33F6, 34F7, 35F8, 36F9 \\
\hline Promotion & 37P1, 38P2, 39P3, 40P4, 41P5, 42P6, 43P7, 44P8, 45P9 \\
\hline
\end{tabular}

Various statistical methods were be used to analyze the data that we collected from the respondents. In this study, the researcher used statistical software SPSS for the statistical analysis. In this study, the responses and information collected from the survey were tested using statistical techniques such as correlation analysis and ANOVA. The Karl Pearson correlation analysis identified and analyzes the nature, direction and signification of the relations between the variables that being measured on interval and ratio data. The hypotheses of research analyzed with ANOVA. 


\section{Hypothesis Development}

On the basis of factors affecting job satisfaction, the following hypotheses are developed:

Hypothesis 1:Work condition significantly influences employee job satisfaction in Banks.

Hypothesis 2:Pay significantly influences employee job satisfaction in Banks.

Hypothesis 3:Fairness significantly influences employee job satisfaction in Banks.

Hypothesis 4:Promotion significantly influences employee job satisfaction in Banks.

Hypothesis 5:Age significantly influences employee job satisfaction in Banks.

Hypothesis 6:Gender significantly influences employee job satisfaction in Banks.

Findings of the Study

A.Descriptive Statistics:

Table 2: Overall level of employee satisfaction in Banks

\begin{tabular}{|l|c|c|c|}
\hline Category & Frequency & Percent & $\begin{array}{l}\text { Cumulative } \\
\text { Percent }\end{array}$ \\
\hline Very unhappy & 11 & 22 & 22 \\
Somewhat unhappy & 10 & 20 & 42 \\
Neither happy nor unhappy & 8 & 16 & 58 \\
Somewhat happy & 12 & 24 & 82 \\
Very happy & 9 & 18 & 100 \\
Total & 50 & 100 & \\
\hline
\end{tabular}

In terms of overall level of employee satisfaction in Banks, the study found that almost one fourth of the respondents perceived employee satisfaction to be "Very unhappy "and "Somewhat happy". Moreover the frequencies of responses don't differ significantly.

Table 3: Descriptive statistics of employee satisfaction in Banks

\begin{tabular}{|c|l|l|c|c|c|}
\hline & $\mathrm{N}$ & Minimum & Maximum & Mean & $\begin{array}{l}\text { Standard. } \\
\text { Deviation }\end{array}$ \\
\hline Level & 50 & 1.00 & 5.00 & 2.96 & 1.442 \\
\hline
\end{tabular}

The mean score is 2.96 and Standard deviation is 1.442. So the overall level of employee job satisfaction is satisfactory.

\section{B. Correlation Analysis:}

Table 4: Pearson Correlation Analysis.

\begin{tabular}{|l|l|l|l|l|l|l|l|}
\hline Variables & $\begin{array}{l}\text { Overall } \\
\text { Satisfaction }\end{array}$ & $\begin{array}{l}\text { Work } \\
\text { Condition }\end{array}$ & Pay & fairness & promotion & Age & Gender \\
\hline Overall Satisfaction & 1 & .680 & .742 & .824 & .886 & .067 & .252 \\
\hline Work Condition & .680 & 1 & .865 & .760 & .649 & .033 & .051 \\
\hline Pay & .742 & .865 & 1 & .863 & .688 & .143 & .157 \\
\hline fairness & .824 & .760 & .863 & 1 & .747 & .194 & .258 \\
\hline promotion & .886 & .649 & .688 & .747 & 1 & -.034 & .183 \\
\hline Age & .067 & .033 & .143 & .194 & -.034 & 1 & .301 \\
\hline Gender & .252 & .051 & .157 & .258 & .183 & .301 & 1 \\
\hline
\end{tabular}

Correlation analysis was used to test the relationship among the variables of interest provided in the study. This study revealed that Work conditions $(0.680)$, pay (0.742), fairness $(0.824)$ and promotion $(0.886)$ had strong relationship with employee job satisfaction in Banks. Age (0.067) and gender (0.252) had weak relationship. 


\section{C.Hypothesis Test:}

Table 5: Hypothesis Test.

\begin{tabular}{|c|c|c|c|c|c|c|}
\hline & & Sum of Squares & $\mathrm{df}$ & Mean Square & $\mathrm{F}$ & Sig. \\
\hline \multirow{3}{*}{$\begin{array}{l}\text { How happy are you with } \\
\text { Work Condition? }\end{array}$} & Between Groups & 34.969 & 4 & 8.742 & 11.733 & .000 \\
\hline & Within Groups & 33.531 & 45 & .745 & & \\
\hline & Total & 68.500 & 49 & & & \\
\hline \multirow{3}{*}{$\begin{array}{l}\text { How happy are you with } \\
\text { Bank basic salary? }\end{array}$} & Between Groups & 48.932 & 4 & 12.233 & 17.230 & .000 \\
\hline & Within Groups & 31.948 & 45 & .710 & & \\
\hline & Total & 80.880 & 49 & & & \\
\hline \multirow{3}{*}{$\begin{array}{l}\text { How happy are you with } \\
\text { work fairness in Bank? }\end{array}$} & Between Groups & 60.707 & 4 & 15.177 & 26.479 & .000 \\
\hline & Within Groups & 25.793 & 45 & .573 & & \\
\hline & Total & 86.500 & 49 & & & \\
\hline \multirow{3}{*}{$\begin{array}{l}\text { How happy are you with } \\
\text { the promotion in Bank? }\end{array}$} & Between Groups & 68.068 & 4 & 17.017 & 42.894 & .000 \\
\hline & Within Groups & 17.852 & 45 & .397 & & \\
\hline & Total & 85.920 & 49 & & & \\
\hline \multirow[t]{3}{*}{ Age } & Between Groups & 3.877 & 4 & .969 & .950 & .444 \\
\hline & Within Groups & 45.903 & 45 & 1.020 & & \\
\hline & Total & 49.780 & 49 & & & \\
\hline \multirow[t]{3}{*}{ Gender } & Between Groups & 1.063 & 4 & .266 & 1.045 & .394 \\
\hline & Within Groups & 11.437 & 45 & .254 & & \\
\hline & Total & 12.500 & 49 & & & \\
\hline
\end{tabular}

Hypothesis1:Work condition significantly influences employee job satisfaction in Banks.

It is assumed from the Null Hypothesis that Work condition does not significantly influences employee job satisfaction in Banks. As table 5 shows significance of work condition(0.000) is lowerthan significance level 0.05 . So the null hypothesis is rejected and hence, we conclude that work condition has significant influences on employee job satisfaction in Banks.

Hypothesis 2:Pay significantly influences employee job satisfaction in Banks.

It is assumed from the Null Hypothesis that pay does not significantly influences employee job satisfaction in Banks. As table 5 shows significance of pay (0.000) is lower than significance level 0.05 . So the null hypothesis is rejected and hence, we conclude that pay has significant influences on employee job satisfaction in Banks.

Hypothesis 3:Fairness significantly influences employee job satisfaction in Banks.

It is assumed from the Null Hypothesis that fairness does not significantly influences employee job satisfaction in Banks. As table 5 shows significance of fairness (0.000) is lower than significance level 0.05. So the null hypothesis is rejected and hence, we conclude that fairness has significant influences on employee job satisfaction in Banks.

Hypothesis 4:Promotion significantly influences employee job satisfaction in Banks.

It is assumed from the Null Hypothesis that promotion does not significantly influences employee job satisfaction in Banks. As table 5 shows significance of promotion (0.000) is lower than significance level 0.05 . So the null hypothesis is rejected and hence, we conclude that promotion has significant influences on employee job satisfaction in Banks.

Hypothesis 5:Age significantly influences employee job satisfaction in Banks.

It is assumed from the Null Hypothesis that Age does not significantly influences employee job satisfaction in Banks. As table 5 shows significance of age (0.444) is higher than significance level 0.05 . So the null hypothesis is accepted and hence, we conclude that age has no significant influences on employee job satisfaction in Banks. Hypothesis 6: Gender significantly influences employee job satisfaction in Banks.

It is assumed from the Null Hypothesis that gender does not significantly influences employee job satisfaction in Banks. As table 5 shows significance of gender (0.394) is higher than significance level 0.05. So the null hypothesis is accepted and hence, we conclude that gender has no significant influences on employee job satisfaction in Banks. 


\section{Limitations of the Study}

Researcher was really unable to collect enough information due to official restrictions of the selected banks. Many things were so confidential that was not entitled to access there. The data obtained from this research is only applicable for Banks in Bangladesh and did not include other sectors of the economy. Thus, the recommendations and suggestions may not be applicable to other country's Banks as well as other sectors.

\section{Recommendations}

Opportunities for future study have emerged as a result of this study. In addition to overcoming the limitations of data gathering, additional research is needed to observe the relationships between job satisfaction and work conditions, pay back, fairness, and promotion. The limitations have contributed to the lack of arriving at many strongly statistically proven findings and conclusions.For future research the following suggestions should be considered:

1) It is suggested that for future research a random sample be used to compare several public sector and private sector institutions using a larger sample.

2) The research is needed to further investigate the potential relationships and effects these variables and other extraneous variables, such as role ambiguity, job level, contingent rewards and co-work have on job satisfaction.

3) Qualitative investigators must conduct research regarding the job satisfaction of Banks.

This research method will provide a different perspective of employees, job satisfaction and contribute a more in-depth understanding of how employees view their job.Based on this study, and analysis of factors affecting Bank employee's job satisfaction, this paper makes the following recommendations to Bank managers:

1) Create favorable work conditions for the company. Guide the staff to communicate effectively, build a good interpersonal environment within the company, and create good work conditions.

2) To improve the pay treatment of Bank employees. Banks should improve the overall wage level of employees; on the other hand, two shifts is a way to reduce the workload of staff.

3) To improve fairness in Banks: create a scientific performance appraisal system in the organization. Utilize the other developed countries' scientific performance systems, and use these systems to evaluate employee work performance and evaluate employee service quality.

4) Concern about the employees education and training. Bank employees generally have high levels of education; organizations have to provide the employees with effective training them in science and cultural knowledge, and let the employees acquire practical knowledge.

\section{Conclusions}

This study focused on the factors that affected job satisfaction in Banks; the central objective of this study was to establish the impact of the chosen variables: work conditions, pay, fairness and promotion and relationships on employee job satisfaction in Banks. A literature survey was made to form the theoretical premises for the study.The rationale for the study was simply an observation that some employees seem better adjusted and happier at work and are able to cope well with the demands of the working environment while others are not. Another observation is that management seems not to be aware of what motivates their subordinates and to strategically utilize those motivational tools to maintain high levels of job satisfaction, high productivity and morale.Through the analysis of Bank employee job satisfaction we can conclude the following: Bank employees are younger, mostly married, with a high level of education, and short years of work experience; there are 9 general factors affecting employee job satisfaction in Bank, which are: work conditions, fairness, promotion, pay, education level, marriage, age and gender, and work experience. There are 4 key factors affecting employee's job satisfaction in Bank: they are: work condition, pay, fairness, and promotion. These four factors are most important in employee job satisfaction. Other individual factors do not have a significant effect on Banks. These factors include have a small effect on job satisfaction in Banks.

\section{References}

Anderson, W. T., Hohenshil, T. H., \& Brown, D. T. (1994). Job Satisfaction among practicing school psychologist. School Psychology Review, 13(2), 225-230.

Barrows, David, Wesson, Tom. A Comparative Analysis of Job Satisfaction among Public and Private Sector Professionals.

Berkowitz, L., Fraser, C., Treasure, F. P., \& Cochran, S. (1987). Pay equity, job gratification, and comparisons in pay satisfaction. Journal of Applied Psychology, 27, 544-551.

Bernal, D., Snyder, D., \& McDaniel, M. (1998). The age and job satisfaction relationship: Does it shape and strength still evade us? Journal of Gerontology:Psychological Services, 53-B(5), 287-293.

Black, M. M., \& Holden, E. W. (1998). The impact on productivity and satisfaction among medical school psychologists. Journal of Clinical Psychology in Medical Settings, 5(1), 117-131. 
Brown, M. B., Hohenshil, T. H., \& Brown, D. T. (1998). Job satisfaction of school psychologists in the United States. School Psychologist International, 19(1),79-89.

Brush, D. H., Moch, M. K., \&Pooyan, A. (1987). Individual demographic differences and job satisfaction. Journal of Occupational Behaviour, 8, 139-155.

Capella, M. E., \& Andrew, J. D. (2004). The relationship between counselor job satisfaction and consumer satisfaction in vocational rehabilitation. Rehabilitation Counseling Bulletin, 47, 205-214.

Carsten, J. M., \& Spector, P. E. (1987). Unemployment, job satisfaction, and employee turnover: a meta-analytic test of the Murchinsky model. Journal of Applied Psychology, 72, 374-381.1

Cheung, C. K., and Scherling, S. A. (1999) "Job Satisfaction, Work Values, and Sex Differences in Taiwan's Organizations".The Journal of Psychology, 133 (5), 563-575.

Eichelberger, Christy (2010). Key Factors in Determining Job Satisfaction. Community for Disabled. Available at www.community.gettinghired.com/ blogs/articles/archive/2010/08/03/key-factors-in-determining-jobatisfaction.aspx.

Kamal, Yasir and Hanif, FawadShaheedZul_kar Ali Bhutto Institute of Science \&Technology (SZABIST), Islamabad. Pay and Job Satisfaction: A Comparative Analysis of Dierent Pakistani Commercial Banks.

Locke, E., (1976). "The Nature and Causes of Job Satisfaction", in Handbook of Industrial/ Organizational Psychology Edited by M.D. Dunnette (Chicago: Rand McNally, 1976): 901-969.

McColl-Kennedy, J. \& Schneider, U. (2000). Measuring job satisfaction: why, what,and how. Total Quality Management. vol. 11 No.7, pp. 883-96.

Murray, M.A., \& Atkinson, T. (2001). Gender differences in correlates of job satisfaction [Electronic version]. Canadian Journal of Behavioral Sciences, 13,44-52.

Navigation, search.Job satisfaction.Wikipedia, the free encyclopedia. Available at www.en.wikipedia.org/wiki/Job_satisfaction.

Nguyen, A. N., Taylor, J., \& Bradley, S. (2003). Relative pay and job satisfaction: some new evidence. http://mpra.ub.uni-muenchen.de/1382, 01 (43).

Sweeney, A. P. Hohenshil, T. H., \& Fortune, J. C. (2002). Job satisfaction among employee assistance professionals: A national study. Journal of Employment Counseling, 39(2), 50-60.

\section{Appendix}

\section{A survey on factors affecting job satisfaction of bank employees in Bangladesh.}

Please take a few moments to complete this questionnaire. The survey focuses on job satisfaction of Bank employees; the actual situation, the detection of problems, trying to improve the management quality of the Bank, rather than the individual employees has any adverse effects. Depending on your individual circumstances, honestly answer every issue, and mark on " $\checkmark$ ", there is only one answer to each question. The success of the survey will depend on your cooperation. All returned questionnaires will be kept strictly confidential, please fill out and return. Thank you for your cooperation and participation.

\section{SECTION A}

Individual information:

Name:

Please mark on " $\checkmark$ "your answer:

\section{Organization:}

1. Gender

Male Female

2. Age

18-29 30-39 40-49 Above 50

3. Marital status Single married

\section{Education level} High school College University

5. Your work department

Human Resource Loan Cash Service Corporate Retail SME manager
other

6. Your work position

General staff Officer Principal Officer Manager other

7. Your Work experience

Half-year 1 year $\quad 1-2 \quad 2-5 \quad$ More than 5 years

8. Your salary
$20,000-30,000$
$30,000-40,000$
$40,000-50,000$
$50,000-60,000$
Above 60,000

More than 50000 
9. Your everyday work hour

4hours 6hours 8hours More than 8hours

SECTION B

Are you happy with the Bank?

How happy are you with the Bank? Please mark on " $\checkmark$ "the answer

Based on the following scale

1 = very unhappy $\quad 2=$ somewhat unhappy $\quad 3=$ neither happy nor unhappy

4 = somewhat happy $5=$ very happy

10. How happy are you with the Bank as overall?
1
2
3
4
5

11. How happy are you with Bank basic salary?
1
2
3
4
5

12. How happy are you with work fairness in Bank?
1
2
34
5

13. How happy are you with the promotion in Bank?
1
2
3
4
5

14 How happy are you with the work environment of the Bank?
1 2
34
5

15 How happy are you with the policy of the Bank?
1
2
34
5

\section{SECTION C}

Employee job satisfaction in Banks: Please mark " $\checkmark$ "the answer Based on the following scale $1=$ strongly disagree $\quad 2=$ disagree $\quad 3=$ natural $4=$ agree $5=$ Strongly agree Work condition at Bank:

\begin{tabular}{|l|l|l|l|l|l|l|}
\hline No. & Statement & $\begin{array}{l}\text { S-dis } \\
\text { agree }\end{array}$ & $\begin{array}{l}\text { Disa } \\
\text { gree }\end{array}$ & $\begin{array}{l}\text { Natu } \\
\text { ral }\end{array}$ & $\begin{array}{l}\text { Agre } \\
\text { e }\end{array}$ & $\begin{array}{l}\text { S-ag } \\
\text { ree }\end{array}$ \\
\hline 16. & Bank supervisor respect the subordinates & 1 & 2 & 3 & 4 & 5 \\
\hline 17. & The Bank is good quality of work environment & 1 & 2 & 3 & 4 & 5 \\
\hline 18. & The Bank have good work condition & 1 & 2 & 3 & 4 & 5 \\
\hline 19. & The atmosphere in the Bank is cheerful & 1 & 2 & 3 & 4 & 5 \\
\hline 20. & Decorations are bright and cheerful & 1 & 2 & 3 & 4 & 5 \\
\hline 21. & The Bank is best quality of management & 1 & 2 & 3 & 4 & 5 \\
\hline 22. & The Bank employees under good relations & 1 & 2 & 3 & 4 & 5 \\
\hline 23. & The Bank manger always help employee & 1 & 2 & 3 & 4 & 5 \\
\hline 24. & The Bank provide good safe work condition & 1 & 2 & 3 & 4 & 5 \\
\hline 25. & The Bank provide good work equipment & 1 & 2 & 3 & 4 & 5 \\
\hline
\end{tabular}

Pay and compensation in Bank:

\begin{tabular}{|l|l|l|l|l|l|l|}
\hline No. & Statement & $\begin{array}{l}\text { S-dis } \\
\text { agree }\end{array}$ & $\begin{array}{l}\text { Disa } \\
\text { gree }\end{array}$ & $\begin{array}{l}\text { Natu } \\
\text { ral }\end{array}$ & $\begin{array}{l}\text { Agre } \\
\text { e }\end{array}$ & $\begin{array}{l}\text { S-ag } \\
\text { ree }\end{array}$ \\
\hline 26. & Bank basic salary is reasonable & 1 & 2 & 3 & 4 & 5 \\
\hline 27. & Bank benefit system is perfect & 1 & 2 & 3 & 4 & 5 \\
\hline
\end{tabular}


Fairness in Bank:

\begin{tabular}{|l|l|l|l|l|l|l|}
\hline No. & Statement & $\begin{array}{l}\text { S-dis } \\
\text { agree }\end{array}$ & $\begin{array}{l}\text { Disa } \\
\text { gree }\end{array}$ & $\begin{array}{l}\text { Natu } \\
\text { ral }\end{array}$ & $\begin{array}{l}\text { Agre } \\
\text { e }\end{array}$ & $\begin{array}{l}\text { S-ag } \\
\text { ree }\end{array}$ \\
\hline 28. & Every employee is treated equally in the Bank & 1 & 2 & 3 & 4 & 5 \\
\hline 29. & I get respect from other employees & 1 & 2 & 3 & 4 & 5 \\
\hline 30. & Bank have fair evaluation system & 1 & 2 & 3 & 4 & 5 \\
\hline 31. & Bank manager fair to communicate with employee & 1 & 2 & 3 & 4 & 5 \\
\hline 32. & Same level of employees received the same salary in Bank & 1 & 2 & 3 & 4 & 5 \\
\hline 33. & Bank exist different work hour for different employee & 1 & 2 & 3 & 4 & 5 \\
\hline 34. & Promotion is fair in Bank & 1 & 2 & 3 & 4 & 5 \\
\hline 35. & Bank provide equal benefits for every employee & 1 & 2 & 3 & 4 & 5 \\
\hline 36. & Bank emphasize fair competition in work place & 1 & 2 & 3 & 4 & 5 \\
\hline
\end{tabular}

\section{Promotion in Bank:}

\begin{tabular}{|l|l|l|l|l|l|l|}
\hline No. & Statement & $\begin{array}{l}\text { S-dis } \\
\text { agree }\end{array}$ & $\begin{array}{l}\text { Disa } \\
\text { gree }\end{array}$ & $\begin{array}{l}\text { Natu } \\
\text { ral }\end{array}$ & $\begin{array}{l}\text { Agr } \\
\text { ee }\end{array}$ & $\begin{array}{l}\text { S-ag } \\
\text { ree }\end{array}$ \\
\hline 37. & promotion rules very clear in Bank & 1 & 2 & 3 & 4 & 5 \\
\hline 38. & promotion depend on employees work performance & 1 & 2 & 3 & 4 & 5 \\
\hline 39. & promotion depends just manager decision & 1 & 2 & 3 & 4 & 5 \\
\hline 40. & Every employee has opportunity to get promotion in Bank & 1 & 2 & 3 & 4 & 5 \\
\hline 41. & Bank have perfect evaluation system & 1 & 2 & 3 & 4 & 5 \\
\hline 42. & Promotion depends on employee relations. & 1 & 2 & 3 & 4 & 5 \\
\hline 43. & $\begin{array}{l}\text { Job performance evaluations done by my supervisor is fair and based } \\
\text { on clear performance standard. }\end{array}$ & 1 & 2 & 4 & 5 \\
\hline 44. & I am satisfied with the Bank promotion policy & 1 & 2 & 3 & 4 & 5 \\
\hline 45. & Promotion can be improve my work attitude & 1 & 2 & 3 & 4 & 5 \\
\hline
\end{tabular}

